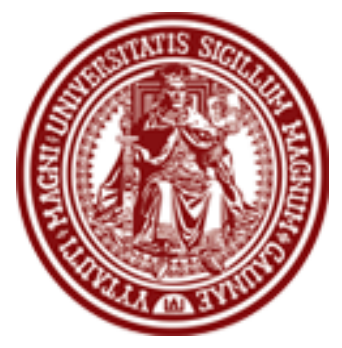

BALTIC JOURNAL OF LAW \& POLITICS

VOLUME 6, NUMBER 2 (2013)

ISSN 2029-0454

http://www.degruyter.com/view/j/bjlp

Cit.: Baltic Journal of Law \& Politics 6:2 (2013): 24-49

DOI: $10.2478 / \mathrm{bjlp}-2013-0010$

\title{
FORWARD-LOOKING SOLUTIONS FOR THE GEORGIAN AND SOUTH OSSETIAN CONFLICT: A PATH TOWARDS RECONCILIATION
}

\section{Gražvydas Jasutis}

Ph.D.; Former Human Security Team Leader at the European Union Monitoring Mission in Georgia Independent Scholar

Contact information

Address: 451-78 str., Brooklyn 11209, USA

Phone: +1 9292451078

E-mail address: grazvydas.jasutis@gmail.com

Received: November 15, 2013; reviews: 2; accepted: December 13, 2013.

\begin{abstract}
The article explores the dynamics of the Georgian and South Ossetian conflict which has been violent over the last twenty years. It reached a critical peak again in 2008 resulting in new security developments and post-conflict situation which drifts away from reconciliation between the communities. The research explains and identifies the timelines and stages of the Georgian-South Ossetian conflict as well as the potential of violence, specifically placing a heavy emphasis on the case of the Akhalgori district, which had been under Georgian control until August 2008. Furthermore, it employs community relations theory and offers forwardlooking solutions which should lead towards reconciliation. The article concludes that reconciliation itself is a very complicated concept to be successfully applied in practice; therefore community relations theory and its approach towards gradual reconciliation between the Georgian and South Ossetian communities seems to be the most reliable option for resolution of the conflict, which should incorporate the Orthodox Church, mutual cultural and anti-intimidation works along with transparent and controllable security actors.
\end{abstract}




\section{KEYWORDS}

Georgia, South Ossetia, reconciliation, conflict, community relations theory

\section{NOTE}

This article is a part of the research "Resolution of Conflicts in the former Soviet Union Area: the Case of Caucasus" conducted by the author at Harriman Institute of Columbia University. The views expressed in the article are those of the author and do not represent the views of other agency or institution. 


\section{INTRODUCTION}

The Georgian and South Ossetian conflict has been often mercurial over the last twenty years, fluctuating between peaceful moments and high-intensity crises which left thousands of refugees and internally displaced persons, a destroyed infrastructure, economy, trade and social life, and killed and maimed inhabitants in Georgia and South Ossetia. It has been five years since the 2008 war between Georgia and Russian started in the context of occupying or liberating South Ossetia, which reached the critical peak again after the 1991-1992, and 2004 bloody strife and reminded the international community of the fragile and vibrant situation in South Caucasus. The 2008 war resulted in the Six Point cease-fire agreement followed by an immediate deployment of the European Union Monitoring Mission (hereinafter referred as EUMM) across the country. Since then South Ossetia has been de jure recognized by the Russian Federation and has taken persistent efforts to make de facto "independence" irreversible and final. Over the last years the multiple processes of borderisation, fencing, passportization, restriction of freedom of movement, security measures and irreconcilable position have increased, which further drove a wedge in Georgian and South Ossetian relationships. The Geneva discussion format has been launched by the international community to handle the post-conflict situation, which remains the only instrument inviting Georgia and South Ossetia and offering solutions at the highest political level. At the lower level the Incident Prevention and Response Mechanism has been embarked on by international stakeholders to discuss mainly incidents along the administrative boundary line (hereinafter referred as $A B L$ ). So far no practical initiatives have been kicked off to begin the reconciliation process between the Georgian and South Ossetian communities which could serve as the cornerstone for further resolution of the conflict.

The Georgian and South Ossetian conflict lacks in deeper analysis and greater attention given by scientists, practitioners and politicians. While many academic papers and analysis can be found on the 2008 war itself and its roots, neither thorough analysis of the potential for reconciliation nor concrete proposals by using practical and theoretical tools have been offered. The current analysis of the conflict has been precisely summarized by Anatol Lieven. Many factors are involved in the present conflict but the central one is straightforward: the majority of the Ossetians living south of the main Caucasus range in Georgia wish to unite with the Ossetians living to the north, in an autonomous republic of the Russian Federation; and the Georgians, regarding South Ossetia as both a legal and an historic part of their 
national territory, refuse to accept this. ${ }^{1}$ Eva Mikhalikova claimed that the conflict between Georgia and South Ossetia is an "intrastate conflict with foreign involvement"; she has analyzed it through the dynamics of foreign politics of various actors. ${ }^{2}$ Similarly Russian and Eurasian specialist Jim Nichol in his peerreview of the conflict in Georgia assessed that the August 2008 war was likely to have long-term effects on security dynamics in the region and beyond. Russia has augmented its long-time military presence in Armenia by establishing bases in Georgia's breakaway Abkhazia and South Ossetia regions. Georgia's military capabilities were at least temporarily degraded by the conflict, and Georgia needed substantial U.S. and NATO military assistance to rebuild its forces. ${ }^{3}$ Professor Nicolai N. Petro analyzed the conflict through the prism of US-Russian relations and concluded that lessons were policy differences with the Russian government and should have be managed pragmatically. To the extent that the Obama administration now appreciates this, there is indeed hope that US relations with Russia can be set on a new path. ${ }^{4}$ In light of the conflict, the US-Georgian relationship has been assessed by Alexander Cooley and Lincoln Mitchell, who claim that the United States should maintain close ties with the Georgian government by nudging it privately to reform while praising it publicly, and wait patiently for Georgia's democracy and economy to flourish so that Abkhazia and South Ossetia feel compelled to rejoin Georgia. ${ }^{5}$ Georgian and South Ossetian authors have published several articles covering the 2008 war from several perspectives and looked for peace. $^{6}$ In 2004 International Crisis group initiated a package of recommendations further updating them in 2007, 2008, 2009, 2010, and 2011 and disseminated to all parties in the conflict. ${ }^{7}$ Though the ideas, content and directions of the recommendations have been priceless, they have never gained traction on a community level and reconciliation.

\footnotetext{
1 Anatol Lieven, "Analysis of Rotos of the Conflict between Georgia, Russia and South Ossetia," The Times (August 11, 2008).

2 Eva Miháliková, "Conflict Analysis of Georgia," Slovenská politologická revue Vol. 1, No. 10 (2010).

$3 \mathrm{Jim}$ Nichol, "Russia-Georgia Conflict in August 2008: Context and Implications for US interests," Congressional Research Service (March 3, 2009) // http://www.fas.org/sgp/crs/row/RL34618.pdf (accessed September 12, 2013).

${ }^{4}$ Nikolai N. Petro, "After Georgia The Russia-Georgia War: Causes and Consequences," Global Dialogue Vol. 11 (Winter/Spring 2009) // http://www.worlddialogue.org/content.php?id=439 (accessed September 12, 2013).

${ }^{5}$ Lincoln Mitchell and Alexander Cooley, "After the August War: A New Strategy for U.S. Engagement with Georgia," Harriman Review Vol. 17, No. 3-4 (2010): 65.

6 Susan Allen Nan, Archil Gegeshidze, George Tarkhan-Mouravi, and Revaz Gachechiladze. GeorgianSouth Ossetian Conflict: Researching Peace (Georgian Foundation for Strategic and International Studies, 2011).

7 "Georgia: Avoiding War in South Ossetia," Europe Report No. 159 (November 26, 2004); "Georgia's South Ossetia Conflict: Make Haste Slowly," Europe Report No. 183 (June 7, 2007); "Russia vs Georgia: The Fallout," Europe Report No. 195 (August 22, 2008); "South Ossetia: The Burden of Recognition," Europe Report No. 205 (June 7, 2010); "Georgia: Securing a Stable Future," Europe Briefing No. 58 (December 13, 2010); "Georgia-Russia: Learn to Live like Neighbours," Europe Briefing No. 65 (August 8, 2011) // http://www.crisisgroup.org/en/regions/europe/south-caucasus/georgia.aspx (accessed August 18, 2013).
} 
Therefore the aim of this article is to comprehensively identify and analyze the potential for reconciliation in light of the Georgian and South Ossetian conflict, with preparation of a list of forward looking actions which could lead to sustainable reconciliation between the communities. The analysis consists of three parts. The first part explains and identifies the timelines and stages of the Georgian-South Ossetian conflict. The second one is focused on the potential for violence in the region, specifically placing a heavy emphasis on the case of the Akhalgori district, which had been under Georgian control until August 2008. It is assumed that Akhalgori still contains various peculiarities that deserve to be treated as the primary source and meeting point for Georgian and South Ossetian interests that might lead to reconciliation. The third part covers community relations theory and offers forward-looking solutions in the case of Akhalgori. Methodologically, there are a significant number of credible conflict analysis methods such as conflict timelines, conflict stages and Attitude-Behavior-Context $(A B C)$ triangle of violence. The establishment of a timeline of the conflict shows the events plotted against a particular time-scale describing chronological line of significant events, views or perceptions which are important to both sides of the conflict. The method of conflict stages helps reveal the conflict cycles and its intensity. The potential existence of violence is analyzed through the $A B C$ violence triangle, which includes behavior, attitudes, and context. A community relations theory has been employed to coin forward-looking proposals for reconciliation. The core principle of community relations theory is that effective intergroup conflict resolution requires significant changes in how people from different communities interact with each other at the local level. ${ }^{8}$

This article draws the conclusion that reconciliation itself is a very intricate concept to be successfully and universally applied in practice; therefore community relations theory and its approach towards gradual reconciliation between the Georgian and South Ossetian communities seems to be the most reliable option for resolution of the conflict, which should incorporate the Orthodox Church, mutual cultural and anti-intimidation works along with transparent and controllable security actors. The international community should be involved in supporting the dialogue of the communities through NGOs, verifying and influencing security actors and creating conducive social and economic conditions.

\footnotetext{
8 Marc H. Ross, "Creating the conditions for peacemaking: theories of practice in ethnic conflict resolution," Ethnic and Racial Studies Vol. 23, Issue 6 (2000).
} 


\section{GEORGIAN AND SOUTH OSSETIAN CONFLICT TIMELINE AND STAGES}

The roots of the Georgian (GEO) and South Ossetian (SO) conflict can be dated back to the beginning of the twentieth century. It had kept an ideological character and its dynamics had been closely related to the then struggle between Bolsheviks and Mensheviks. In 1918-1920 the Ossetian peasants supported by Bolsheviks had harshly opposed Georgian rule and nationalistic-oriented authorities and had demanded independence. This had resulted in several thousands of victims and brutal repressions undertaken by Georgian side. The Soviet Union capitalized on the turmoil and further escalation of the conflict and invaded Georgia. Consequently, the Soviet Republic of Georgia was forcibly established in 1921 along with the South Ossetian Autonomous District, which obtained a status of autonomy within the Republic in 1922. From then on, both the Georgian and South Ossetian communities cohabitated in the Soviet Union and it did not spark off any serious confrontations. The period can be marked by Russification, forced resettlement from mountainous area to lowland, and pretty tense relations between Tskhinvali and Tbilisi. Nevertheless, at a grass-root level GEO and SO communities lived side by side and socially interacted (i.e. intermarriage, went to the same schools). This short historical discourse is important to note to conceptually perceive the current stage of the conflict and its dynamics.

The modern conflict between Georgia and South Ossetia revived along with national renaissance in the former Warsaw Pact area which resulted in the collapse of the Soviet Union, newly established independent states, ethnic mobilization in the Caucasus, revision of history, justice, spread of democracy and explosion of ethnic conflicts. In 1989 the South Ossetian Supreme Council decided to unite with North Ossetia and the decision can be considered as a starting point of the timeline to be established when analyzing the conflict between two communities. In conflict management methodology, an establishment of a timeline of the conflict remains very simple and crucially valuable analytical tool. In fact it shows the events plotted against a particular time-scale describing chronological line of significant events, views or perceptions which are important to each side of the conflict. ${ }^{9}$ The timeline depicted below shows the most important events related to the conflict and it partly covers the perceptions of them as being assessed by the conflict parties.

\footnotetext{
${ }^{9}$ Simon Fisher, ed., Working with Conflict: Skills and Strategies for Action (Zed Books, 2000).
} 
Table No 1. Conflict timeline ${ }^{10}$

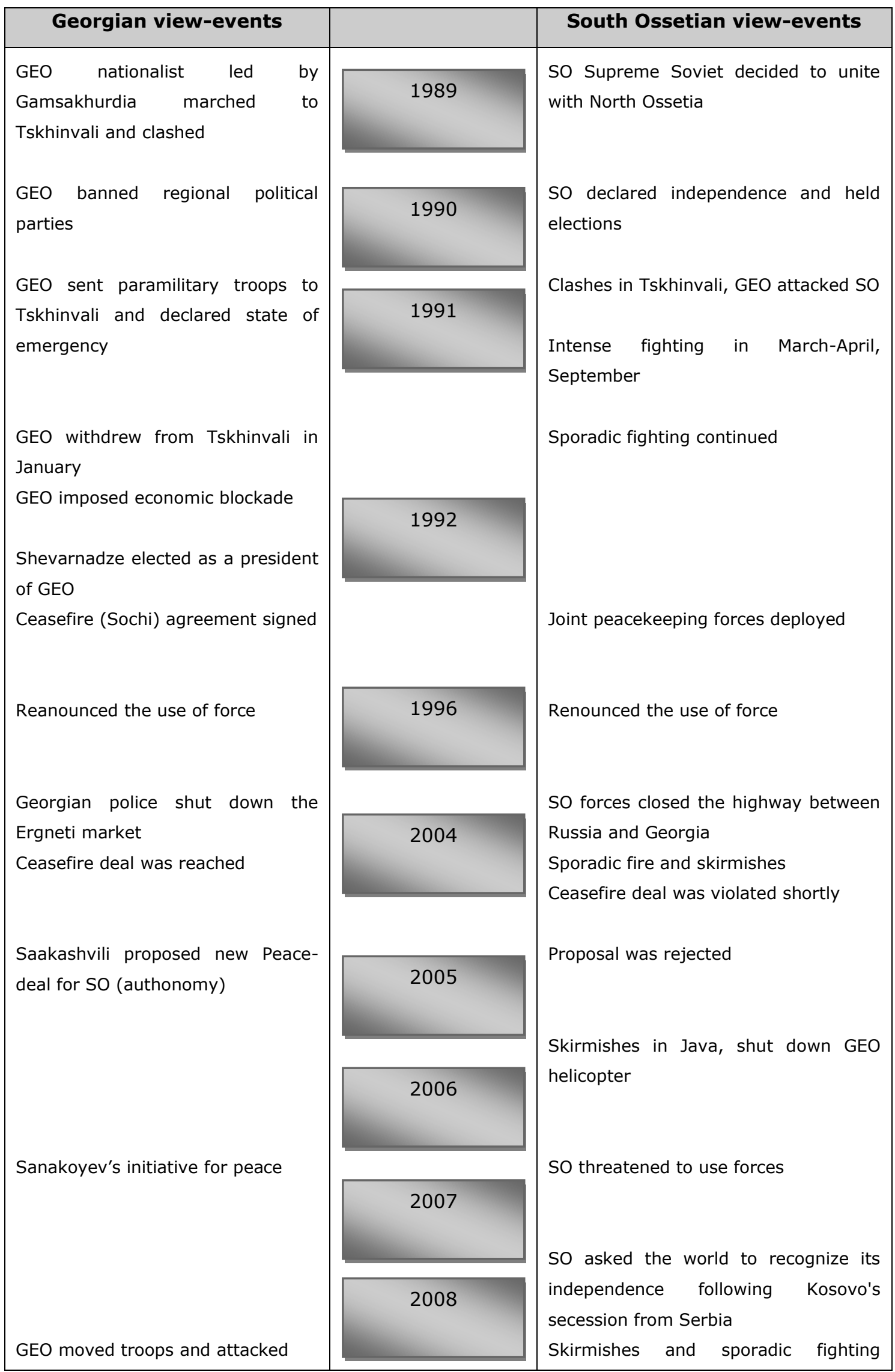

${ }^{10}$ Selected and prepared by the author. 
Ceasefire agreement signed

continued

RUS troops intervened

As depicted in the timeline, in Georgian-South Ossetian conflict both sides perceive and understand the conflict in different way. They tend to emphasize different events and provide another logic of event assessments. Methodologically the timeline does not aim at disclosing true facts; rather, it puts the events in chronological order and explains the perceptions of the conflict parties. With nationalistic uprising in Georgia and South Ossetia it was probably impossible to escape the conflict. Both sides intended to pursue the nationalistic policy. The then GEO leader Gamsakhurdia exposed himself with slogan "Georgia to Georgians" and abolished SO autonomy while SO elite declared independence, organized elections and did not recognize GEO authorities. This led to bloody armed clashes in 19911992. The conflict was temporally suspended in Sochi when GEO and SO signed a Sochi agreement and later on joint peace-keeping forces were deployed in the region. The period between 1992 and 2008 can be assessed as volatile turbulent one enriched with provocations and small-medium scale scrimmages from both sides. Quite logically it led to another conflict between Georgia and Russia where the bone of contention was South Ossetia. The conflict lasted only five days; however, it resulted in hundreds of deaths and new political architecture in South Caucasus. ${ }^{11}$ South Ossetia was officially recognized as an independent state by the Russian Federation followed by some Pacific and Latin America countries. A sixpoint cease-fire agreement between Georgia and Russia under the umbrella of the European Union was signed and the European Union monitoring mission was deployed. The outcome of the conflict is perceived in a different way. The GEO side considers that the Russian Federation occupied $20 \%$ of its territory and broke all norms of international law while the South Ossetian side claims that Russia liberated them from GEO occupation and brought freedom and independence in the region.

The timeline depicted above is a very helpful tool for establishing stages of the conflict and estimating its intensity. Though scientists and practitioners tend to provide various cycles and stages of the conflict, ${ }^{12}$ it is commonly agreed by

\footnotetext{
11 The Georgian side claimed losses of 170 servicemen, 14 policemen and 228 civilians killed and 1747 persons wounded. The Russian side claimed losses of 67 servicemen killed and 283 wounded. The South Ossetians spoke of 365 persons killed, which probably included both servicemen and civilians. Altogether about 850 persons lost their lives, not to mention those who were wounded, who went missing, or the far more than 100000 civilians who fled their homes. See more at: Report of Independent International Fact-Finding Mission on the Conflict in Georgia, Presented to the Council of the European Union, Vol. 1 (September 2009).

12 Different authors name and describe these stages differently. Actual conflicts usually do not follow a linear path. Rather, they evolve in fits and starts, alternatively experiencing progress and setbacks
} 
practitioners that a conflict consists of five stages. The first stage is pre-conflict, which is marked by incompatibility of goals between two parties. There may be tension between them and avoidance of contacts. The second stage is confrontation when parties may engage in volatile behavior and small skirmishes. The polarization and violence between parties tend to increase. The third stage is considered as crisis, which is the height of the conflict marked by high intensity violence and fighting. The crisis often leads to the fourth stage which is called the outcome. The outcome can be different. It can lead to occupation, ethnic cleansing, negotiation or decreased violence. The fifth stage is post-conflict, which indicates that the situation is resolved and the parties are ready for new co-existence and a new quality of relationship. The conflict stages help identify the most intense and turbulent period and predict the future of the conflict. As has been already mentioned, the Georgian-South Ossetian conflict resulted in a cease-fire agreement sponsored by the EU. However it is important to note at which stage the ceasefire agreement was negotiated and what its strategic value is in the given context of cyclical conflict stages.

\section{Conflict escalation}

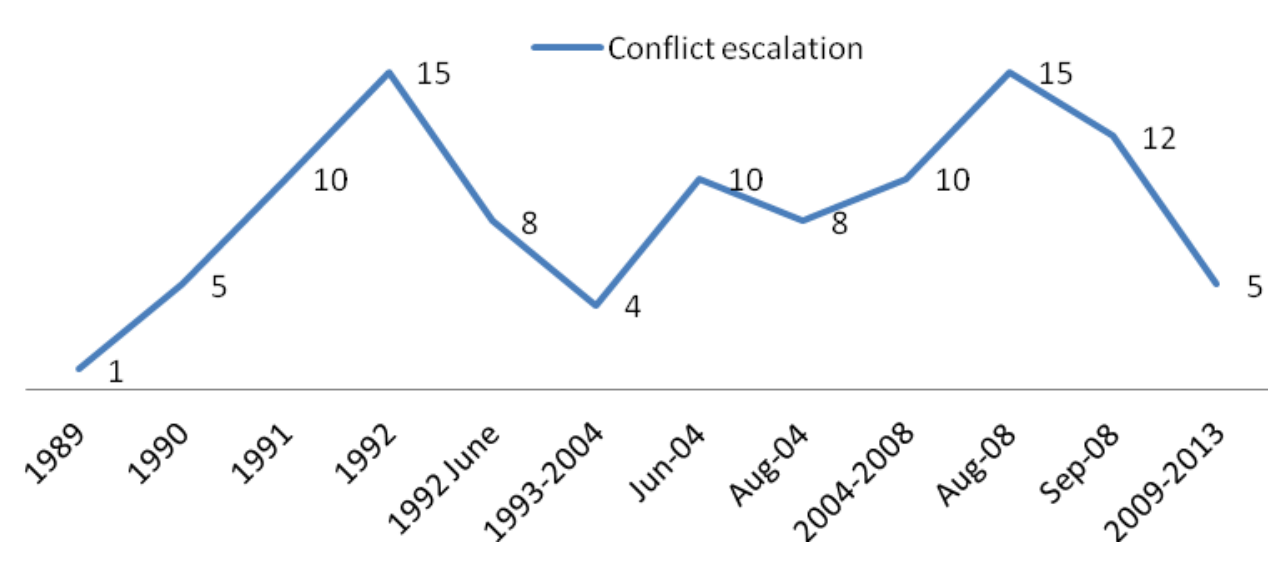

Fig. 1. Conflict Stages ${ }^{13}$

1-5 points - Pre-conflict (can be conflict outcome or post-conflict), 5-10 pointsConfrontation (can be conflict outcome or post-conflict), 10-15 points - Crisis

As the chart indicates, the GEO-SO conflict has experienced all five stages starting from pre-conflict in 1989, which subsequently led to confrontation between GEO and SO communities and crisis in 1991-1992. The outcome of the crisis was the Sochi agreement, which to some extent curbed the aggressive intentions of 
both conflict parties and joint peace-keeping forces were deployed to prevent any further escalation. The period of 1994-2004 can be assessed as a post-conflict stage with confrontational elements. It witnessed neither serious clashes between the parties nor substantial negotiations leading to credible peace (except 1996 agreement renouncing the use of force). In the course of 2004-2008 the parties confronted each other on a frequent basis and violated the Sochi agreement. The new government in GEO conducted a policy focused on reunification of the country and it was quite successful in the case of the Ajara Republic. The conflict reached two peaks again in summer of 2004 and 2008 with some hiatus in between. The latter took five days of intense fighting and resulted in hundreds of deaths and approximately 100.000 IDPs. The conflict stages clearly indicate the cyclical character of the conflict. The 1992 Sochi agreement (outcome) did not solve the problems and the post-conflict period did not lead to reconciliation between the GEO and SO communities. The 2008 Six Points agreement seemed to be a reliable tool to introduce stability in the region; however it does not contain any measure which could facilitate reconciliation between the communities. This does not necessarily imply that the situation will evolve into a crisis in the future. The problem is that at the given post-conflict situation no win-win situation can be observed and at the present stage (post-conflict) the problems keep arising from incompatibility of goals (the most important is GEO territorial integrity) and the parties might return back to confrontation or even crisis.

\section{THE DYNAMICS OF VIOLENCE WITHIN THE CONFLICT: THE CASE OF} AKHALGORI

The potential existence of violence shakes up each and every conflict. The international community tends to misunderstand the concept of violence, attributing it to behavior resulting in killing, maiming and torturing people. In fact, violence must be understood as a structural and contextual manifestation that includes behavior, attitudes, values, institutions, personalities and other categories. 


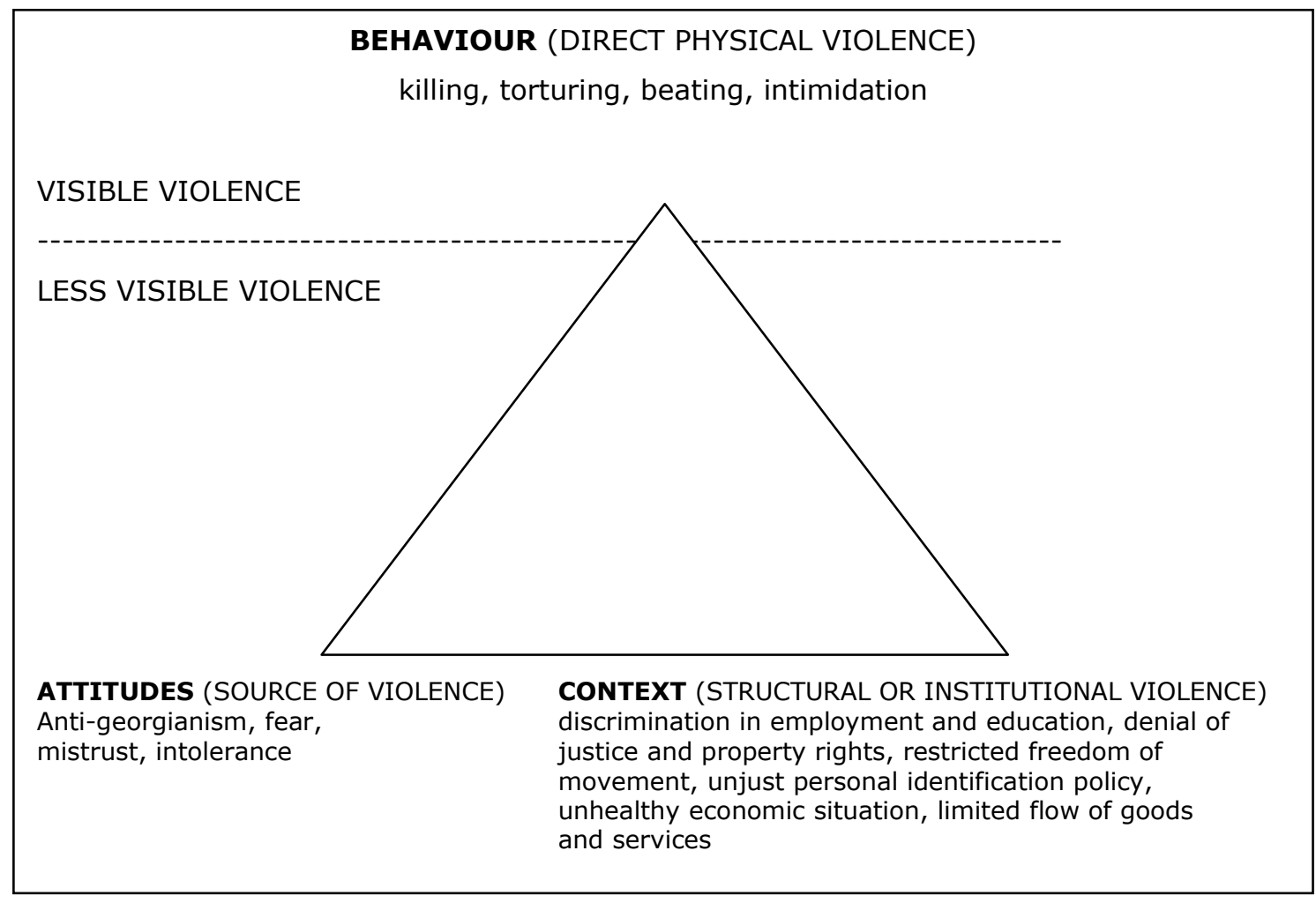

Fig. 2. ABC Triangle ${ }^{14}$

The triangle of violence depicted above demonstrates three main parts of violence and shows how they function. The first angle is behavior which is the most visible and clearly expressed part of the violence. It includes killing, maiming, or torturing people and international community mainly deals with or pays greater attention to it. The second angle encompasses a context, which may incorporate structural and institutional violence causing negative attitudes, mistrust and intolerance (the third angle). The latter might be transformed into physical violence, thus crafting a vicious circle and preventing the discovery of a formula for conflict resolutions.

As has been mentioned, the GEO-SO conflict has evolved into two peaks leading to physical violence and crisis in 1991-1992 and 2008 (2004 violence can be attribute to the crisis as well). It clearly demonstrates that the concept of violence was totally misperceived and no credible strategy towards reconciliation was adopted. Therefore, the case of Akhalgori could serve as a good example of non-physical violence and its consequences and as a window of opportunity for reconciliation. The Akhlagori district is pretty unique in the dynamics of the GEO-SO

\footnotetext{
14 Developed and adapted by author from: Johan Galtung, "Cultural Violence," Journal of Peace Research Vol. 27, No. 3 (August 1990); Christopher Mitchell, The Structure of International Conflict (St. Martin's Press, 1989), p. 355; Simon Fisher, supra note 9, p. 224.
} 
conflict. ${ }^{15}$ It had belonged to the Duseti district until the Autonomous District of South Ossetia was established. It consisted of three territorial fragmentsAkhalgori, Lehuri and Monasterski-which were fused and entitled as Leningori honoring former soviet leader Vladimir Lenin. On the $4^{\text {th }}$ of September 1990 the Regional Council of Leningori decided to rename the region and return its previous name - Akhalgori. The Council of Autonomous Republic of South Ossetia frowned harshly on the decision and considered it against the law. In 1991-1992 Akhalgori was under control of the GEO side and it stayed in their power until the 2008 conflict (except some parts of Lekhuri Valley and lowland of Trifunski). After 1992 the Akhalgori part controlled and administered by the SO side was called Leningori and its capital was Tsinagar, while the GEO Akhalgori was administered from Tbilisi and its center was located in Akhalgori town. In 1995 the GEO Akhalgori part was added to Mtskheta-Mtianeti district and in 2007 GEO president M. Saakashvili issued a decree to hand over Akhlagori district to the jurisdiction of the temporary administration of the South Ossetia Autonomous District which was recognized by GEO authorities.

The Akhalgori district suffered neither from major battles nor skirmishes during the 2008 conflict. SO armed volunteers invaded Akhalgori on the 11 of August 2008 and did not shoot any rounds over there. On the $4^{\text {th }}$ of September the SO governmental commission arrived in Akhalgori and presented a new chief of administration, Anatoli Margeev, who represented the interests and jurisdiction of the SO side ${ }^{16}$. In fact, it meant that the Akhalgori district was fully incorporated into So. The physical occupation of Akahlgori went with no atrocities or physical violence in the area, according to those who witnessed. ${ }^{17}$ Admittedly, looting, human rights violations, intimidation and robbing took place and NGOs recorded some examples such as robbing and battering schools in Akhalgori. ${ }^{18}$ Health care service in remote areas stopped functioning and locals were intimidated. Six thousand Georgians were forced to be relocated from Akhalgori IDPs settlements in Tserovani, Tsilkani, and Prezeti built in Tbilisi administered territory. There had

${ }^{15}$ Historical facts in the paragraph are taken from the following sources: Marija Kotaeva, "Leningorskij rajon: politicheskie osobennosti, demograficheskie harakteristiki, jekonomika, pogranichnye problemy" (District of Leningori: Political Peculiarities, Demographic Features and Economic Cross-border Problems) (2011) //

http://cardata.gmu.edu/docs/papers/2011SouthOssetianAuthors.pdf (accessed September 18, 2013); Gražvydas Jasutis, "Gruzijos ir Pietu Osetijos konfliktas: Akhalgori rajono atvejis" (Georgian and South Ossetian Conflict: the Case of Akhalgori), NGO Trust in Developement (2013) //

http://trustdevelopment.eu/v2/wp-content/uploads/2013/06/studija-alhalgori-final.pdf (accessed September 18, 2013).

16 "Zhiteljam Leningori predstavili novogo glavu administracii" (New Head of Administration Was Introduced to Leningori Inhabitants) (2008) // http://sojcc.ru/rus/1628.html (accessed September 18, 2013).

17 "Polozhenie gruzinskogo naselenija Leningorskogo rajona Respubliki Juzhnaja Osetija (Ahalgorskogo rajona Gruzii) vyzyvaet ser'eznoe bespokojstvo" (Situation of Georgians in Leningori South Ossetia Remains Serious) (2008) // http://www.memo.ru/d/2252.html (accessed September 18, 2013).

${ }^{18}$ Ibid. 
been three ethnic groups in Akhalgori which prevailed - Georgian, Ossetian and Armenian. Georgian and Ossetian groups represented ethnic majority, while the Armenian group the minority. The population in Akhagori tended to decrease due to poor economic situation, bad social service, miserable infrastructure in the mountainous area and a grim future.

Table No. 2. Akhalgori ethnic breakdown 1939-197919

\begin{tabular}{|c|c|c|c|c|}
\hline Year & Population & Georgian & Ossetian & Armenian \\
\hline 1939 & 22.725 & 38.8 & 57.3 & 2.8 \\
\hline 1959 & 16.770 & 42.3 & 53.4 & 3.5 \\
\hline 1970 & 14.543 & 47.9 & 48.4 & 2.7 \\
\hline 1979 & 13.772 & 51.5 & 46.5 & 1.2 \\
\hline
\end{tabular}

Te last poll conducted in the GEO controlled part of Akhalgori took place in 2002 and it rather precisely indicated the number of population and its ethnicity.

Table No. 3. Akhalgori ethnic breakdown $2002^{20}$

\begin{tabular}{|c|c|c|}
\hline Ethnicity & Population & Percents \\
\hline Georgian & 6520 & $84,64 \%$ \\
\hline Ossetian & 1110 & $14,41 \%$ \\
\hline Armenian & 37 & $0,48 \%$ \\
\hline Russian & 20 & $0,26 \%$ \\
\hline Abkhaz & 6 & $0,08 \%$ \\
\hline Azerbaijani & 2 & $0,03 \%$ \\
\hline Greek & 2 & $0,03 \%$ \\
\hline Ukrainian & 1 & $0,01 \%$ \\
\hline Izid & 1 & $0,01 \%$ \\
\hline Kist & 0 & - \\
\hline Total & 7703 & $100,00 \%$ \\
\hline
\end{tabular}

At the moment the South Ossetian authorities do not provide population data though seemingly there are 2500 inhabitants in Akhalgori (based on information related to the elections to SO parliament 2009)..$^{21}$ Ethnic breakdown is important because in most cases violence occur between people belonging to different

\footnotetext{
${ }^{19}$ Marija Kotaeva, supra note 15.

20 Ibid.

${ }^{21}$ Ibid.
} 
ethnicities. Returning to the triangle of violence and its management, it is worth mentioning that behavior or direct physical violence did not take place in Akhalgori. Of course, NGOs registered a number of beatings which resulted in one death; however, outbursts of direct physical violence did not happen in Akhalgori. ${ }^{22}$ The main sources of instability and violence so far are concentrated within structures and institutions. In the course of the conference "The Problems of the Akhalgori district: IDPs and their future" organized in August 2013, the following conclusion was drawn to depict the situation. ${ }^{23}$ As mentioned in the conference final communiqué, security measures taken by de facto authorities have complicated the maintenance of irrigation channels, blocked traditional access routes and trails, and sometimes led to the arrest of persons crossing the administrative boundary line; moreover, the inability to access fields, orchards, traditional grazing grounds, forests and markets has reduced income and employment opportunities ${ }^{24}$. SO de facto authorities issues Form No 9, which authorize restricted travel to and from Akhalgori for a limited amount of Akhalgori residents. Furthermore, it has made significant efforts to request residents of Akhalgori to take a South Ossetian passport and refuse a Georgian one. Hence, the structures and institutions contribute to the increased negative attitudes and disunity within GEO and SO communities. Logically, negative attitudes will further hasten and provoke aggressive behavior leading to the continuation of the conflict and physical violence.

\section{COMMUNITY RELATIONS THEORY IN SEARCH OF RECONCILIATION BETWEEN GEORGIA AND SOUTH OSSETIA}

The core principle of community relations theory is that effective intergroup conflict resolution requires significant changes in how people from different communities interact with each other at the local level. ${ }^{25}$ This theory is instrumental and provides a variety of tools to reconcile various communities that are at conflict. According to Hugh Frazer and Mari Fitzduff, ${ }^{26}$ the term community relations was coined in the early sixties in Britain and pertained to solutions being sought there in relation to the problem of racial disharmony, arising from the immigration of

\footnotetext{
22 Situation of Georgians in Leningori South Ossetia Remains Serious, supra note 17.

${ }^{23}$ International Appeal Following the Conference "The Problems of Akhalgori District: Internally Displaced Persons and their Future" (2013) // http://trustdevelopment.eu/v2/wpcontent/uploads/2013/06/TIDappeal-ENG_final2.pdf (accessed September 19, 2013).

${ }^{24}$ International Appeal Following the Conference "The Problems of Akhalgori District: Internally Displaced Persons and their Future" (2013) // http://trustdevelopment.eu/v2/wpcontent/uploads/2013/06/TIDappeal-ENG_final2.pdf (accessed September 19, 2013).

${ }^{25}$ Marc H. Ross, supra note 8.

26 Hugh Frazer and Mari Fitzduff, "Improving Community Relations," Community Relations Council, CRC Pamphlet No. 3 (1994): 58; Mari Fitzduff, "Approaches to Community Relations," Community Relations Council, CRC Pamphlet No. 1 (1991): 36.
} 
various African and Asian peoples to the United Kingdom. They claim that earlier definitions of the objectives of community relations work seem to have primarily concerned themselves with emphasizing the idea of a harmonious existence between differing groups, with the intended goal of integrating the minority groups into the wider community as quickly as possible; later definitions of objectives have put a far greater emphasis on the idea of equality of basic rights and opportunity for all groups, whilst simultaneously encouraging cultural diversity, as being preferable contemporary objectives of community relations work ${ }^{27}$. The theory emphasizes three main aspects of community relations which should lead to reconciliation: ${ }^{28}$

- Improving communication and understanding between communities;

- Promoting a tolerant acceptance of existence of diversity of cultures and customs;

- Encouraging structures which safeguard the rights of all members of the society.

In principle, a two-stage approach first targets the communities separately supporting multiple initiatives at the grass root level to strengthen civil society and prepare for reconciliation and confidence building with the other side. Therefore, the first stage in fact begins with the process of enabling and creating the civil society sector within a single entity that is capable of addressing its issues independently and participates in the process leading to tolerance and further communication. At the second stage of community relations, the interaction starts between the communities through dialogue, joint projects and initiatives to support mutual understanding and reconciliation. The core assumption is that functional cooperation around substantive matters can contribute to breakdown of negative images and reduce intergroup hostility and violence. ${ }^{29}$ Though Hugh Frazer and Mari Fitzduff limit themselves to two stages, it is necessary to underscore the role of local institutions (context) and third parties. Many ethnic conflicts witness an influx of international organizations, mediators, prominent leaders, international NGOs that make an attempt to contribute to the resolution of the conflict. This aspect is of crucial importance because a great part of community relations activities is engulfed by a neutral arbiter (be it international organization or NGO) which attempts to link the communities and neutralize the role of biased local institutional structures.

In analyzing the reconciliation between the GEO and SO communities and possible confidence building, the first stage (focusing on single communities) does

\footnotetext{
27 Ibid.

${ }^{28}$ Marc H. Ross, supra note 8.

${ }^{29}$ Hugh Frazer and Mari Fitzduff, supra note 26: 58; Mari Fitzduff, supra note 26: 36.
} 
not need much attention due to two reasons. As previously mentioned, the first stage begins with the process of developing civil society sector within single communities; however the community in the Akhalgori district was under Georgian control and it was sufficiently developed. Secondly, both conflicting sides support their communities as single entities through various social and economic projects and this suggests that the first stage has been reached so that the main priority should be given to the second stage where much of the investment should be made in interaction processes between the communities. Eventually Hugh Frazer and Mari Fitzduff offers eight areas to improve communication and understanding between the communities which should lead to promoting a tolerant acceptance of existence of diversity of cultures and customs of the GEO and SO communities ${ }^{30}$.

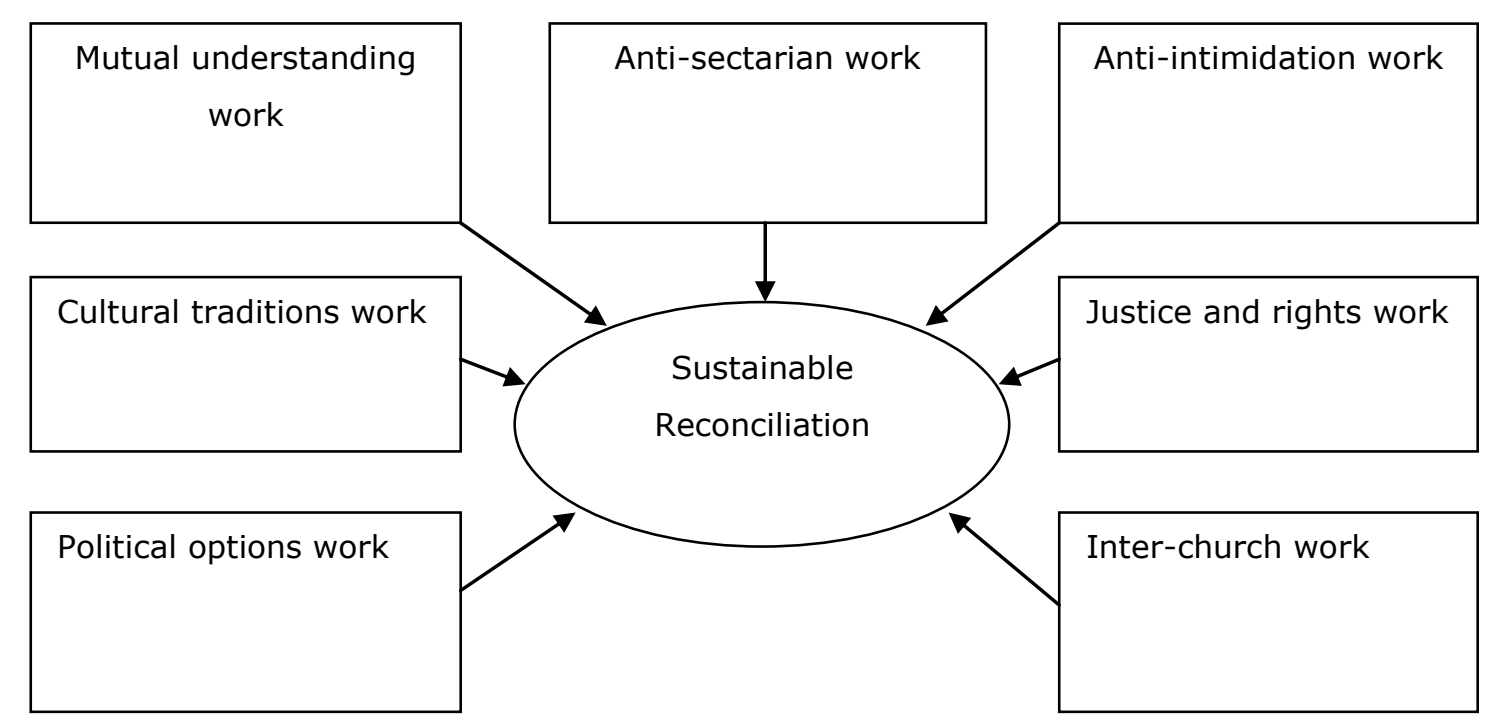

Fig. 3. Structure of sustainable reconciliation ${ }^{31}$

As depicted in the chart, the reconciliation between the GEO and SO communities can be based on seven points (Hugh Frazer and Mari Fitzduff suggest including an eighth point - work on reconciliation) to be addressed through different channels and ways. It is suggested to start with mutual understanding work, which aims at bringing communities closer focusing on establishing sound contacts and sharing the information between the communities. In the case of Akhalgori, the residents of Akhalgori may cross ABL with proper documentation issued by de facto authorities and this measure of freedom helps to maintain communication channels open and to share the information between the communities. Collective initiatives between women of Akhagori would be a good

\footnotetext{
30 Ibid.

31 Prepared by the author; developed and adapted from: Hugh Frazer and Mari Fitzduff, supra note 26: 58; Mari Fitzduff, supra note 26: 36
} 
start for this, as well as school exchange visits to improve the communication between specific members of the communities.

Anti-intimidation work should concentrate on reducing inter-community intimidation levels. In the fall of 2008 a number of physical violence actions took place in Akhalgori, seeding the intimidation and fear between the communities. The presence and role of security actors in Akhalgori remain one of the most important issues to be addressed. The conflicts often boost security sector reforms focused on recalibrating and readapting those security forces that participated in the conflict and whose role in the conflict was rather questionable. In the light of conflict in Akhalgori accompanied with tension and instability, former Georgian security institutions and frameworks were replaced by Russian and South Ossetian structures which are biased and associated with physical, social and political violence (from Georgian perspective). There are Russian Border Guards (RF BG), Russian Armed forces, South Ossetian Police and South Ossetian KGB in Akhalgori. ${ }^{32}$ While the RF Border guard service seemed to be professional, So Police tended to be overwhelmingly involved in illegal activities and relatively protected only one single entity. It is obvious that SO security actors have tarnished their reputation and their ability to keep social balance between governmental structures and individuals remain questionable. Therefore it is important to permanently challenge SO security actors behavior, and mutual discussions to tackle the issues should play an important role. A representative of the community could attend weekly or monthly meetings with SO police and RF BG.

It is worth also mentioning the cultural traditions work. Both the GEO and SO communities cohabited and shared some cultural elements and customs due to geographical proximity, history and Caucasian identity. The cultural diversity between the communities cannot be observed as a major sticking point to be addressed. One suggestion is to organize joint events to commemorate cultural holidays from both sides; for example, the $15^{\text {th }}$ of October is the birthday of famous Ossetian Poet Kosta Khetagurov, and the $15^{\text {th }}$ of May is the Day of Ossetian Language and Literature. Similar Georgian holidays should be commemorated in South Ossetia as well. In other words, cultural confidence well supported by the institutional structures and implemented through multiple grass-root level initiatives would satisfy the needs of both communities and contribute to reconciliation. Joint publications, seminars, conferences, cultural visits, dance and

32 "Chetvertaja voennaja baza Minoborony RF polnost'ju razmeshhena v Juzhnoj Osetii" (Fourth Military Base of RF Ministry of Defense has been fully deployed) (2010) // http://www.kavkaz-uzel.ru (accessed September 15, 2013); "Bufernaja zona posle vyvoda ottuda rossijskih vojsk" (Buffer zone after withdrawal of Russian troops) (2008) // http://www.memo.ru/2008/10/28/2810081.html (accessed September 15, 2013); "Rossijskie pogranvojska pribyli v Juzhnuju Osetiju ohranjat' granicu s Gruziej" (Russian border guards arrived in South Ossetia to protect the border with Georgia), Rossiskaja gazeta No. 4911 (87) (May 18, 2009). 
song festivals, literature events would support reconciliation and improve communication between the communities.

Justice and rights work seems to be quite emotional and challenging, and needs to be addressed between the communities. There are a lot of methodological tools to soften the process of justice and rights works which offer creation of social media tools to exchange the stories among the victims, TV and radio show, direct contacts with an independent arbiter, etc. As mentioned in the Handbook on reconciliation, the past has many layers and this fact needs to be acknowledged before addressing the (past) future through a reconciliation process ${ }^{33}$. Each victim has his/her story to tell and in most cases the stories encompass violence, misbehavior, war crime, and human rights violations. Therefore, the quest for truth and justice - essential stages on the way to reconciliation - does not simply disappear with time. The political imposition of "forgiving and forgetting" may fail completely to stifle demands for the prosecution ${ }^{34}$. There are a number of cases on property rights and confiscations in Akhalgori that have been recorded by international communities and presented in Geneva discussions. This should be addressed through local and international channels to make sure that justice and rule of law prevails.

Though it is unlikely to happen in the near future, political option work might offer new opportunities for the community. This should include community discussions with politicians in Akhalgori and Tserovani who are responsible for the fate of their people. Joint events representing both sides would bring people together and might find solutions for their problems.

Cooperation between the churches in South Ossetia and Georgia is another area to be seriously considered. Both Ossetian and Georgian communities are Orthodox. However, though the South Ossetian Church de jure belongs to the canonical territory of the Georgian Orthodox Church, ecclesiastical rule from Tbilisi has not been de facto or carried out for over fifteen years and the eparchies of South Ossetia and Abkhazia have been insisting on independence from the Georgian Patriarchy ${ }^{35}$. Setting aside the canonical disputes, the role of church in reconciliation should be underscored. The Orthodox Church remains the most trusted institution in Georgia. In a 2013 February survey carried out by the Caucasus Resource Research Center (CRRC), 95\% of respondents had a favorable

\footnotetext{
33 David Bloomfield and Theresa Barnes, eds., Reconciliation After Violent Conflict. A Handbook (2003) // http://www.idea.int/publications/reconciliation/ (accessed November 11, 2013).

${ }^{34}$ Ibid.

35 Elena Maler-Matyazova, "The Unrecognized Eparchies of the Recognized Republics," www.katehon.ru (2009) // http://www.katehon.ru/html/top/eccleo/nepriznannie_eparhii_Eg.htm (accessed September $15,2013)$.
} 
opinion of its work. ${ }^{36}$ What is more, Patriarch Ilia's influence in Georgia and even in the Caucasus region is unquestionable. Polls conducted by US companies show that his approval rating has never been lower than $92 \% .{ }^{37}$ He supports restoration of the relationship between the communities (though his stance was completely different back in the 90's). He was born in Vladikavkaz (North Ossetia), graduated from high school there and his spiritual father was the Ossetian, Father Mikhail Dzatsoev $^{38}$. His experience and positive attitude should be employed and used to the full extent possible. Presently, Akhalgori is covered spiritually by the Georgian bishop residing in Nikozi, whose connections and personal characteristics could contribute to reconciliation. Joint bible studies, focused church services, exchange of prayers and pilgrims, joint social activities (i.e. charity event) should be extensively right-targeted actions leading the communities towards the mutual understanding and communication.

The areas of work must provide a sound basis for sustainable reconciliation; however, at some point, the involvement of governmental structures or third actors should be more than welcome. ${ }^{39}$ Governmental agencies and international organizations (in this case European Union Monitoring Mission in Georgia, EU Delegation in Georgia, UN office in Georgia) possess substantial political and administrative resources to support the dialogue between the communities. Civil society and local NGOs in conflict affected areas are always vulnerable, fragile, poorly organized and under-resourced. As mentioned in the final communiqué of an Akhalgori conference ${ }^{40}$, the Akhalgori IDP community is often marginalized from mainstream NGO support, and calls for deeper engagement; local NGOs working with conflict-resolution and the IDP community need professional and structural development support. The role of the international community or an independent arbiter to organize the meetings between governmental structures and civil society to ensure continued dialogue would be of tremendous importance. Furthermore, governmental agencies and international actors possess more serious leverage to make influence on security structures which tend to misbehave and still remain the

\footnotetext{
36 "Georgia's mighty Orthodox Church," www.bbc.co.uk (July 2, 2013) // http://www.bbc.co.uk/news/world-europe-23103853 (accessed September 15, 2013).

37 Nadezhda Kevorkova, "Patriarch of Georgia: Our Church and People Never Cut Ties with Russia," rt.com (July 22, 2013) // http://rt.com/op-edge/patriarch-georgia-russia-ties-438/ (accessed September $15,2013)$.

38 Nadezhda Kevorkova, "Patriarch of Georgia: Our Church and People Never Cut Ties with Russia," rt.com (July 22, 2013) // http://rt.com/op-edge/patriarch-georgia-russia-ties-438/ (accessed September $15,2013)$.

${ }^{39}$ Hugh Frazer and Mari Fitzduff point out that contextual community relations work should be focused on community development, trusted and accessible security forces, pluralist environments, targeting social need and training in critical thinking (Hugh Frazer and Mari Fitzduff, supra note 26: 58; Mari Fitzduff, supra note 26).

${ }^{40}$ International Appeal Following the Conference "The Problems of Akhalgori District: Internally Displaced Persons and their Future" (2013) // http://trustdevelopment.eu/v2/wpcontent/uploads/2013/06/TIDappeal-ENG_final2.pdf (accessed September 19, 2013).
} 
source of instability. Robust channels of communication should be established between the communities and security actors with support of EUMM basing on the principle of mutual trust and confidence. The development of social and cultural institutions (sport clubs, discussion forums, cultural houses) between the GEO and SO communities should be started and some funding should be allocated. This would lead to more contact between the communities, better communication, a higher degree of confidence and would reduce the level of intimidation or violence. Needless to say, both Georgia and South Ossetia suffer from chronicle economic disease(s) such as unemployment, poor infrastructure, and lack of labor skills. Training can be the cornerstone of unemployment response. On September 18, 2013, so de facto authorities enforced new rules to limit the ability to cross ABL for Akhalgori and Tserovani residents ${ }^{41}$. While not all of the forecasted changes took place, the rules of the border crossing have already begun tightening and the situation is still unresolved; it means hindered travelling, trading and communication and these changes are especially directed against trade - while cross-bordering is still possible for individuals, bringing and taking goods to sell in Akhalgori is from now on forbidden ${ }^{42}$. These changes have had detrimental effect on daily life of IDPs and Akhalgori residents who lost their jobs and source of income. Governmental agencies and international community should take some actions targeting social and economic issues for good reasons including reconciliation. Moreover, South Ossetia is engulfed by Russia and Georgia in all aspects and the revival of trade zone or market along $A B L$ or adjacent territories, would serve as a bonanza for both sides.

With this in mind, an independent arbiter or credible international organization could make a substantial contribution to conflict management and reconciliation. It is worth specifying a particular role of the third parties to be played in case of Akhalgori where EU has been largely involved in the post-conflict management issues and its further engagement is a key element in solving this conflict. It would be important to make use of all instruments the EU possesses to facilitate the social-political dialogue, improve communication and provide robust assistance to the conflict parties. The EU should further support Georgia in implementing its strategy on soft engagement with South Ossetia and encourage their economic, cultural and scientific initiatives across the ABL. One suggestion would be to employ an "intense contacts approach" based on development aid and

41 Postanovlenie pravitel'stva RJuO ob organizacii peresechenija gosudarstvennoj granicy Respubliki Juzhnaja Osetija s Gruziej v uproshhennom porjadke 15 fevralja 2011 goda No 26 (Decree of the Government of South Ossetia on organizing the facilitated crossing regime with Georgia) (2011) // http://cominf.org/node/1166488996 (accessed September 30, 2013).

42 "The Issues of Akhalgori District: IDPs and Their Future," trustdevelopment.eu (2013) // http://trustdevelopment.eu/?page_id=53 (accessed 15 November, 2013). 
interaction to ensure communication channels with de facto authorities in order to solve all questions stemming from community needs, to support NGO sector working on confidence building on both sides, to develop and maintain arrangements for funding of initiatives aimed at reconciliation process, and to mainstream human rights and gender issues in conflict management with specific focus on the IDPs, and empowerment of women towards long term reconciliation.

\section{CONCLUSION}

This article has gone through the GEO-SO conflict timelines, stages, and violence, and has analyzed the potential for reconciliation and confidence building at the community level. While unambiguous conclusions cannot be drawn, the following objective points related to the researched topic and problem should be underscored:

The GEO-SO conflict stages clearly indicate the cyclical process within the dynamics of the conflict. It oscillates between crisis and a relatively peaceful coexistence leading to another confrontation. The 1992 Sochi cease-fire agreement had not prevented further bloodshed and the 2008 Six-point agreement, which seems to be a reliable tool for stability between the conflict parties, does not contain the appropriate norms needed for reconciliation. Moreover, the existing incompatibility of the goals in the case of Georgian infringed territorial integrity, might encourage the parties to return to the conflict.

The level of violence in the GEO-SO conflict has been fluctuating and it has been evolving over the years depending on security and geo-political factors. Admittedly, behavioral violence based on killing and torturing people used to occur for shorter periods during the peak of conflicts. Meanwhile contextual and structural violence provoking negative and harmful attitudes at a community level has been observed over the whole period of the conflict and misperception of the violence concept and absence of concrete interventions to stop it, has kept the door open for further evolution of the conflict. A package of well-elaborated actions targeting contextual and structural violence are needed to prevent the conflict from further development as the analysis of Akhalgori case has clearly demonstrated. The case of Akhalgori has been very important to demonstrate that behavioral violence has not prevailed in the district and it, as less conflict affected, may serve as a starting point for reconciliation.

The reconciliation between GEO and SO communities should be achieved through improving communication and understanding between the communities, promoting a acceptable of existence of different languages, identities and cultures, 
and encouraging structures which safeguard the rights of both communities, as community relations theory suggests. Seven areas have been explored to improve communication between the communities and increase the level of tolerance. Great importance should be attached to joint cultural work activities supporting mutual cultural event, festivals and exhibitions. Anti-intimidation work should contribute to the establishment of trust and security between the communities and the transparency of security actors in Akhalgori district remains one of the most important issues to be addressed. In terms of community relations and confidence building, the security actors cannot facilitate the process because it does not contribute to the development of public order between GEO and SO individuals. It is of tremendous importance to challenge unacceptable behavior and practice of the security actors which does not support reconciliation and confidence building between the communities. The most important part in reconciliation between the communities should be attributed to the Orthodox Church, which remains a very powerful actor in both communities. It is worth noting that Patriarch Ilia's influence in Georgia is unprecedented and he supports the restoration of the relationship between the communities. His Ossetian background, experience and positive attitude should be employed and used to the full extent possible.

Community relations theory does not elaborate on the significant involvement of the third parties to support confidence building and reconciliation between the communities. The theory does not neglect its influence, but neither does it foresee a noteworthy role for it. This article concludes that the international community (as the third party) should be involved in supporting the dialogue of the communities through NGOs, verifying and influencing security actors and creating conducive social and economic conditions. More particularly, the European Union should remain impartial as is and assist all parties involved in creating dialogue, supporting social initiatives, mainstreaming human rights, and boosting regional cooperation. Of course, the governmental agencies should support and facilitate the whole process. South Ossetia is engulfed by Russia and Georgia and the revival of trade zone or market along $A B L$ in adjacent territories would serve as a benefit for both sides. This could be done exclusively through governmental channels. It is very important to engage the Ossetian community living in the Tbilisi controlled territory through providing them exclusive rights to learn in Ossetian and preserve their culture. Their positive feedback might engage the Ossetians living in South Ossetia, thus enabling them to contribute to reconciliation and the confidence building process between the communities. The creation of joint institutions for reconciliation and confidence building between relevant agencies at lower levels, and the establishment of an information share mechanism (to facilitate the 
exchange of documents or provide urgent information) would be of great importance. Reconciliation itself is a complex and difficult concept to be successfully and universally applied in practice; therefore community relations theory and its approach towards gradual reconciliation between the communities seems to be the most reliable option for resolution of the conflict.

\section{BIBLIOGRAPHY}

1. Bloomfield, David, and Theresa Barnes, eds. Reconciliation After Violent Conflict. A Handbook. 2003 // http://www.idea.int/publications/reconciliation/ (accessed November 11, 2013).

2. Brahm, Eric. "Conflict Stages." www.beyondintractability.org (September 2003) // http://www.beyondintractability.org/essay/conflict-stages (accessed July 10, 2013).

3. "Bufernaja zona posle vyvoda ottuda rossijskih vojsk" (Buffer Zone after Withdrawal of Russian Troops) (2008) //

http://www.memo.ru/2008/10/28/2810081.html (accessed September 15, 2013) [in Russian].

4. "Chetvertaja voennaja baza Minoborony RF polnost'ju razmeshhena v Juzhnoj Osetii" (Fourth Military Base of RF Ministry of Defense Has Been Fully Deployed) (2010) // http://www.kavkaz-uzel.ru (accessed September 15, 2013) [in Russian].

5. Fisher, Simon, ed. Working With Conflict: Skills and Strategies for Action. Zed Books (2000).

6. Fitzduff, Mari. "Approaches to Community Relations." Community Relations Council. CRC Pamphlet No. 1 (1991).

7. Frazer, Hugh, and Mari Fitzduff. "Improving Community Relations." Community Relations Council. CRC Pamphlet No. 3 (1994).

8. Galtung, Johan. "Cultural Violence." Journal of Peace Research Vol. 27, No. 3 (August 1990): 291-305.

9. "Georgia: Avoiding War in South Ossetia." Europe Report No. 159 (November 26, 2004) // http://www.crisisgroup.org/en/regions/europe/southcaucasus/georgia.aspx (accessed August 18, 2013).

10. "Georgia's South Ossetia Conflict: Make Haste Slowly." Europe Report No. 183 (June 7, 2007) // http://www.crisisgroup.org/en/regions/europe/southcaucasus/georgia.aspx (accessed August 18, 2013). 
11. "Georgia's Mighty Orthodox Church." www.bbc.co.uk (July 2, 2013) // http://www.bbc.co.uk/news/world-europe-23103853 (accessed September 15, 2013).

12. "Georgia: Securing a Stable Future." Europe Briefing No. 58 (December 13, 2010) // http://www.crisisgroup.org/en/regions/europe/southcaucasus/georgia.aspx (accessed August 18, 2013).

13. "Georgia-Russia: Learn to Live like Neighbours." Europe Briefing No. 65 (August 8, 2011) // http://www.crisisgroup.org/en/regions/europe/southcaucasus/georgia.aspx (accessed August 18, 2013).

14. International Appeal Following the Conference "The Problems of Akhalgori District: Internally Displaced Persons and their Future." NGO Trust in Development (2013) // http://trustdevelopment.eu/v2/wpcontent/uploads/2013/06/TIDappeal-ENG_final2.pdf (accessed September 19, 2013).

15. Jasutis, Gražvydas. "Gruzijos ir Pietu Osetijos konfliktas: Akhalgori rajono atvejis" (Georgian and South Ossetian Conflict: the Case of Akhalgori). NGO Trust in Development (2013) // http://trustdevelopment.eu/v2/wpcontent/uploads/2013/06/studija-alhalgori-final.pdf (accessed September 18, 2013) [in Lithuanian].

16. Kevorkova, Nadezhda. "Patriarch of Georgia: Our Church and People Never Cut Ties with Russia." rt.com (July 22, 2013) // http://rt.com/opedge/patriarch-georgia-russia-ties-438/ (accessed September 15, 2013).

17. Kotaeva, Marija. "Leningorskij rajon: politicheskie osobennosti, demograficheskie harakteristiki, jekonomika, pogranichnye problemy" (District of Leningori: Political Peculiarities, Demographic Features and Economic Cross-border Problems) (2011) // http://cardata.gmu.edu/docs/papers/2011SouthOssetianAuthors.pdf (accessed September 18, 2013) [in Russian].

18. Lieven, Anatol. "Analysis of Rotos of the Conflict between Georgia, Russia and South Ossetia." The Times (August 11, 2008).

19. Maler-Matyazova, Elena. "The Unrecognized Eparchies of the Recognized Republics." www.katehon.ru (2009) // http://www.katehon.ru/html/top/eccleo/nepriznannie_eparhii_Eg.htm (accessed September 15, 2013).

20. Mitchell, Christopher. The Structure of International Conflict. St. Martin's Press, 1989.

21. Miháliková, Eva. "Conflict Analysis of Georgia." Slovenská politologická revue Vol. 1, No. 10 (2010): 59-83. 
22. Mitchell, Lincoln, and Alexander Cooley. "After the August War: A New Strategy for U.S. Engagement with Georgia." Harriman Review Vol. 17, No. 34 (2010): 1-69.

23. Nan, Susan A., Archil Gegeshidze, George Tarkhan-Mouravi, and Revaz Gachechiladze. Georgian-South Ossetian Conflict: Researching Peace. Georgian Foundation for Strategic and International Studies, 2011.

24. Nichol, Jim. "Russia-Georgia conflict in August 2008: Context and Implications for US interests." Congressional Research Service (March 3, 2009) // http://www.fas.org/sgp/crs/row/RL34618.pdf (accessed September 12, 2013).

25. Petro, Nikolai N. "After Georgia The Russia-Georgia War: Causes and Consequences." Global Dialogue Vol. 11 (Winter/Spring 2009) // http://www.worlddialogue.org/content.php?id=439 (accessed September 12, 2013).

26. "Polozhenie gruzinskogo naselenija Leningorskogo rajona Respubliki Juzhnaja Osetija (Ahalgorskogo rajona Gruzii) vyzyvaet ser'eznoe bespokojstvo" (Situation of Georgians in Leningori South Ossetia Remains Serious) (2008) // http://www.memo.ru/d/2252.html (accessed September 18, 2013) [in Russian].

27. Postanovlenie pravitel'stva RJuO ob organizacii peresechenija gosudarstvennoj granicy Respubliki Juzhnaja Osetija s Gruziej v uproshhennom porjadke 15 fevralja 2011 goda No 26 (Decree of the Government of South Ossetia on Organizing the Facilitated Crossing Regime with Georgia) (2011) // http://cominf.org/node/1166488996 (accessed September 30, 2013) [in Russian].

28. Report of Independent International Fact-Finding Mission on the Conflict in Georgia. Presented to the Council of the European Union. Vol. 1 (September 2009).

29. "Rossijskie pogranvojska pribyli $v$ Juzhnuju Osetiju ohranjat' granicu $s$ Gruziej" (Russian Border Guards Arrived in South Ossetia to Protect the Border with Georgia). Rossiskaja gazeta No. 4911 (87) (May 18, 2009) [in Russian].

30. Ross, Marc H. "Creating the conditions for peacemaking: theories of practice in ethnic conflict resolution." Ethnic and Racial Studies Vol. 23, Issue 6 (2000): 1002-1034.

31. "Russia vs Georgia: The Fallout." Europe Report No. 195 (August 22, 2008) // http://www.crisisgroup.org/en/regions/europe/south-caucasus/georgia.aspx (accessed August 18, 2013). 
32. "South Ossetia: The Burden of Recognition." Europe Report No. 205 (June 7, 2010) // http://www.crisisgroup.org/en/regions/europe/southcaucasus/georgia.aspx (accessed August 18, 2013).

33. "The Issues of Akhalgori District: IDPs and Their Future." trustdevelopment.eu (2013) // http://trustdevelopment.eu/?page_id=53 (accessed November 15, 2013).

34. "Zhiteljam Leningori predstavili novogo glavu administracii" (New Head of Administration Was Introduced to Leningori Inhabitants) (2008) // http://sojcc.ru/rus/1628.html (accessed September 18, 2013) [in Russian]. 